\title{
Changing perspective on tissue processing - comparison of microwave histoprocessing method with the conventional method
}

\author{
Shrestha $\mathrm{G}^{1}$, Karki $\mathrm{S}^{1}$, Pradhan $\mathrm{A}^{1}$ \\ ${ }^{I}$ Department of Pathology, B. P. Koirala Institute of Health Sciences, Dharan, Nepal.
}

\section{Keywords: \\ Histoprocessing; \\ Microwave; \\ Tissue; \\ Pathology.}

\section{INTRODUCTION}

Histopathological examination of tissues requires sliver of formalin fixed tissue that has been chemically processed and then stained with Haematoxylin and Eosin. The time

\section{Correspondence:}

Dr. Girishma Shrestha, MBBS, MD

Intrepid Cancer Diagnostics,Kathmandu, Nepal

Email: girishma.path@gmail.com

\begin{abstract}
Background: Histopathological examination of tissues requires sliver of formalin fixed tissue that has been chemically processed and then stained with Haematoxylin and Eosin. The time honored conventional method of tissue processing, which requires 12 to 13 hours for completion, is employed at majority of laboratories but is now seeing the trend of being replaced by microwave method owing to the latter's ability to reduce turn-around time significantly.

The study was aimed at analyzing if microwave method of tissue processing and staining could produce results as good as the conventional method.

Materials and Methods: This was a hospital based comparative cross sectional study done at Department of Pathology, B.P. Koirala Institute of Health Sciences, Nepal, between March 2013 and February 2014. A semi-automated microwave was used and a total of hundred pairs of tissue sections were evaluated by two pathologists blinded to the nature of processing and staining method used. Grades were given for the histomorphologic quality based on seven different parameters: cellular clarity, cytoplasmic details, nuclear details, color intensity, interface of epithelium and connective tissue, fibrous tissue component and stain quality.

Results: No statistically significant variation $(p>0.05)$ was observed between the microwave and conventional methods in terms of overall quality and diagnostic contribution. Complete concordance between the two methods with regard to quality was seen in an average of $90.42 \%$ cases. None of the slides were graded 'poor'.

Conclusion: Microwave histoprocessing and staining method produced results as good as a routine method giving an advantage of shortened tissue processing cycle along with the elimination of hazardous chemicals such as xylene and overall without significant decrement in diagnostic utility.
\end{abstract}

honored conventional method of tissue processing, which requires 12 to 13 hours for completion, is employed at majority of laboratories but is now seeing the trend of being replaced by microwave method owing to the latter's ability to reduce turn-around time significantly.

Quality of structural preservation of tissue components is determined by the choice of reagent and exposure time to the 


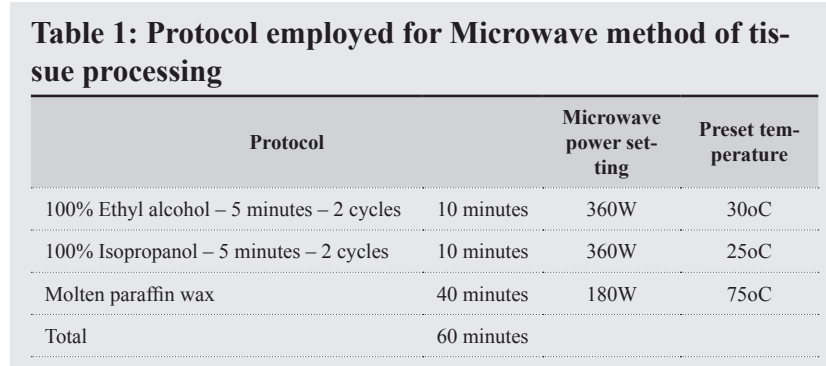

For the conventional method, Tissue Tek II - Tissue processor (Sakura) was used.

reagents during processing. The physico-chemical basis of tissue processing is the diffusion of reagents to the substance of the tissue to be processed and can be accelerated with application of heat. Microwaves quickly and uniformly heat materials without the use of convectional heat.

With this study, we analyzed if the microwave method of tissue processing combined with staining can produce results as good as the conventional method in surgical pathology laboratory at B. P. Koirala Institute of Health Sciences.

\section{MATERIALS AND METHODS}

This was a comparative, cross-sectional hospital based study carried out in Department of Pathology, B.P. Koirala Institute of Health Sciences, Nepal. Systematic randomized sampling was done of specimens received at the department between March 2013 to February 2014. Hundred pairs of samples were taken. Consent for the study was taken from the Institutional Ethical Review Board, B.P.K.I.H.S before the commencement of the study.

Grossing Specimen received at the laboratory in $10 \%$ buffered formalin were stored to be grossed the next day. Two tissue sections of $15 \times 10 \times 3 \mathrm{~mm}^{3}$ were taken from each specimen and randomly divided to be processed by different methods after proper coding. Tissue sections were placed in plastic cassettes for Microwave group and in metal cassettes for Conventional group.

Steps for both the methods included:
- $\quad$ clearing,

- impregnation,

- $\quad$ embedding,

- microtomy,

- deparaffinization,

- $\quad$ hematoxylin and eosin staining

For the microwave method, we opted for a semi-automated laboratory grade microwave $(\mathrm{BP} \neg 110$ Laboratory Microwave - Microwave Research and Applications) over a consumer grade domestic microwave because of its uniform wave distribution throughout its chamber. It is equipped with manually controlled power and time settings and biopsy specimens are transferred to different reagents by hand.

Four to five samples were processed at a time. They were immersed in $200 \mathrm{ml}$ of reagents in beakers of $400 \mathrm{ml}$ capacity that were loosely covered during irradiation. Time required for exchanging reagents in between steps was kept to minimal. Preset temperature was fixed for each reagent so as to maintain uniformity between each batch. Ethanol: $30^{\circ} \mathrm{C}$, Isopropanol: $25^{\circ} \mathrm{C}$ Molten wax: $75^{\circ} \mathrm{C}$

\section{RESULTS}

\section{Haematoxylin and Eosin staining:}

After deparaffinization, sections were hydrated through decreasing grade of ethyl alcohol ( $95 \%$ and $70 \%)$ and washed in running tap water for 3 minutes. Sections were allowed to be irradiated at $360 \mathrm{~W}$ while immersed in Hematoxylin (Harris) for 40 seconds. This was followed by Blueing in running tap water for 5 minutes and differentiated in $0.1 \%$ $\mathrm{HCl}$ (1 dip 2 seconds) and rinsed in running tap water for 5 minutes. Sections were again irradiated at $360 \mathrm{~W}$ while immersed in Eosin for 25 seconds, followed by dehydration in $95 \%$ alcohol and absolute alcohol for 3 minutes each. All the slides were mounted with DPX and properly coded.

- Dehydration,

Table 2 : Comparison of mean scores obtained by the two methods (Conventional method and Microwave method)

\begin{tabular}{|c|c|c|c|c|c|c|c|c|c|c|c|c|c|c|c|}
\hline \multicolumn{2}{|c|}{ Parameters } & \multicolumn{2}{|c|}{ Cellular clarity } & \multicolumn{2}{|c|}{ Cytoplasmic Details } & \multicolumn{2}{|c|}{ Nuclear Details } & \multicolumn{2}{|c|}{ Colour Intensity } & \multicolumn{2}{|c|}{$\begin{array}{l}\text { Epithelium and } \\
\text { connective tissue } \\
\text { interface }\end{array}$} & \multicolumn{2}{|c|}{$\begin{array}{l}\text { Fibrous tissue } \\
\text { component }\end{array}$} & \multicolumn{2}{|c|}{ Staining quality } \\
\hline $\begin{array}{l}\text { Method } \\
\text { employed }\end{array}$ & $\mathrm{N}$ & $\begin{array}{l}\text { Mean } \\
\text { Score }\end{array}$ & $\begin{array}{l}\text { Std } \\
\text { Devia- } \\
\text { tion }\end{array}$ & $\begin{array}{l}\text { Mean } \\
\text { Score }\end{array}$ & $\begin{array}{l}\text { Std } \\
\text { Deviation }\end{array}$ & $\begin{array}{l}\text { Mean } \\
\text { Score }\end{array}$ & $\begin{array}{l}\text { Std } \\
\text { Deviation }\end{array}$ & $\begin{array}{l}\text { Mean } \\
\text { Score }\end{array}$ & $\begin{array}{l}\text { Std } \\
\text { Deviation }\end{array}$ & $\begin{array}{l}\text { Mean } \\
\text { Score }\end{array}$ & $\begin{array}{l}\text { Std } \\
\text { Deviation }\end{array}$ & $\begin{array}{l}\text { Mean } \\
\text { Score }\end{array}$ & $\begin{array}{l}\text { Std } \\
\text { Deviation }\end{array}$ & $\begin{array}{l}\text { Mean } \\
\text { Score }\end{array}$ & $\begin{array}{l}\text { Std } \\
\text { Deviation }\end{array}$ \\
\hline $\begin{array}{l}\text { Conventional } \\
\text { method }\end{array}$ & 100 & 7.97 & 0.3 & 7.97 & 0.3 & 7.96 & 0.4 & 7.84 & 0.526 & 7.95 & 0.359 & 7.87 & 0.506 & 7.84 & 0.545 \\
\hline $\begin{array}{l}\text { Microwave } \\
\text { method }\end{array}$ & 100 & 7.98 & 0.141 & 7.96 & 0.243 & 7.93 & 0.355 & 7.95 & 0.297 & 7.91 & 0.351 & 7.81 & 0.563 & 7.91 & 0.379 \\
\hline
\end{tabular}




\section{Table 3 : Wilcoxon signed ranks test - Conventional method vs Microwave method}

\begin{tabular}{|c|c|c|c|c|c|c|c|c|c|c|c|c|c|c|c|c|c|c|c|c|c|}
\hline \multirow{2}{*}{$\begin{array}{l}\text { Parameters } \\
\text { Method } \\
\text { employed }\end{array}$} & \multicolumn{3}{|c|}{ Cellular clarity } & \multicolumn{3}{|c|}{ Cytoplasmic Details } & \multicolumn{3}{|c|}{ Nuclear Details } & \multicolumn{3}{|c|}{ Colour Intensity } & \multicolumn{3}{|c|}{$\begin{array}{l}\text { Epithelium and } \\
\text { connective tissue } \\
\text { interface }\end{array}$} & \multicolumn{3}{|c|}{$\begin{array}{l}\text { Fibrous tissue } \\
\text { component }\end{array}$} & \multicolumn{3}{|c|}{ Staining quality } \\
\hline & $\mathrm{N}$ & $\begin{array}{l}\text { Mean } \\
\text { Rank }\end{array}$ & $\begin{array}{l}\text { Sum of } \\
\text { Ranks }\end{array}$ & $\mathrm{N}$ & $\begin{array}{l}\text { Mean } \\
\text { Rank }\end{array}$ & $\begin{array}{l}\text { Sum of } \\
\text { Ranks }\end{array}$ & $\mathrm{N}$ & $\begin{array}{l}\text { Mean } \\
\text { Rank }\end{array}$ & $\begin{array}{l}\text { Sum of } \\
\text { Ranks }\end{array}$ & $\mathrm{N}$ & $\begin{array}{l}\text { Mean } \\
\text { Rank }\end{array}$ & $\begin{array}{l}\text { Sum of } \\
\text { Ranks }\end{array}$ & $\mathrm{N}$ & $\begin{array}{l}\text { Mean } \\
\text { Rank }\end{array}$ & $\begin{array}{l}\text { Sum of } \\
\text { Ranks }\end{array}$ & $\mathrm{N}$ & $\begin{array}{l}\text { Mean } \\
\text { Rank }\end{array}$ & $\begin{array}{l}\text { Sum of } \\
\text { Ranks }\end{array}$ & $\mathrm{N}$ & $\begin{array}{l}\text { Mean } \\
\text { Rank }\end{array}$ & $\begin{array}{l}\text { Sum of } \\
\text { Ranks }\end{array}$ \\
\hline $\begin{array}{l}\text { Conventional } \\
>\text { Microwave }\end{array}$ & 2 & 1.50 & 3.00 & 3 & 2.00 & 6.00 & 4 & 2.50 & 10.00 & 3 & 7.50 & 22.50 & 7 & 4.14 & 29.00 & 11 & 9.18 & 101.00 & 6 & 7.00 & 42.00 \\
\hline $\begin{array}{l}\text { Microwave > } \\
\text { Conventional }\end{array}$ & 1 & 3.00 & 3.00 & 1 & 4.00 & 4.00 & 1 & 5.00 & 5.00 & 10 & 6.85 & 68.50 & 2 & 8.00 & 16.00 & 7 & 10.00 & 70.00 & 9 & 8.67 & 78.00 \\
\hline $\begin{array}{l}\text { Conventional } \\
=\text { Microwave }\end{array}$ & 97 & - & - & 96 & - & - & 95 & - & - & 87 & - & - & 91 & - & - & 82 & - & - & 85 & - & - \\
\hline $\mathrm{p}$ Value & \multicolumn{3}{|c|}{1.000} & \multicolumn{3}{|c|}{0.713} & \multicolumn{3}{|c|}{0.492} & \multicolumn{3}{|c|}{0.100} & \multicolumn{3}{|c|}{0.431} & \multicolumn{3}{|c|}{0.483} & \multicolumn{3}{|c|}{0.295} \\
\hline
\end{tabular}

Table 4: Overall working time for the two methods (microwave conventional methods)

\begin{tabular}{lcc}
\hline & $\begin{array}{c}\text { Time required for } \\
\text { Microwave method }\end{array}$ & $\begin{array}{c}\text { Time required for } \\
\text { Conventional method }\end{array}$ \\
\hline Tissue processing & 60 minutes & 12 hours \\
\hline $\begin{array}{l}\text { Deparaffinization } \\
\text { Hematoxylin and Eosin } \\
\text { staining }\end{array}$ & 30 minutes & 30 minutes \\
$\begin{array}{l}\text { Approximate time } \\
\text { required }\end{array}$ & 18 minutes & 21 minutes \\
\hline
\end{tabular}

\begin{tabular}{|c|c|c|c|c|}
\hline Procedure & $\begin{array}{l}\text { Min. Temp. } \\
(\mathrm{oC})\end{array}$ & $\begin{array}{l}\text { Max. Temp } \\
\quad(\mathrm{oC})\end{array}$ & Mean & $\begin{array}{l}\text { Std. } \\
\text { Deviation }\end{array}$ \\
\hline $\begin{array}{l}100 \% \text { Ethyl Alcohol - Dehydra- } \\
\text { tion step }\end{array}$ & 55 & 71 & 63.53 & 3.607 \\
\hline $\begin{array}{l}100 \% \text { Isopropyl Alcohol - Clear- } \\
\text { ing step }\end{array}$ & 73 & 78 & 75.53 & 1.605 \\
\hline
\end{tabular}

End-Temperature log was maintained after each step in every batch. The mean end-temperature recorded by thermometer after dehydration step was $63.53^{\circ} \mathrm{C}$ (maximum $71^{\circ} \mathrm{C}$ and minimum $55^{\circ} \mathrm{C}$ ) and after clearing step was $75.53^{\circ} \mathrm{C}$ (maximum $78^{\circ} \mathrm{C}$ and minimum $73^{\circ} \mathrm{C}$ ).

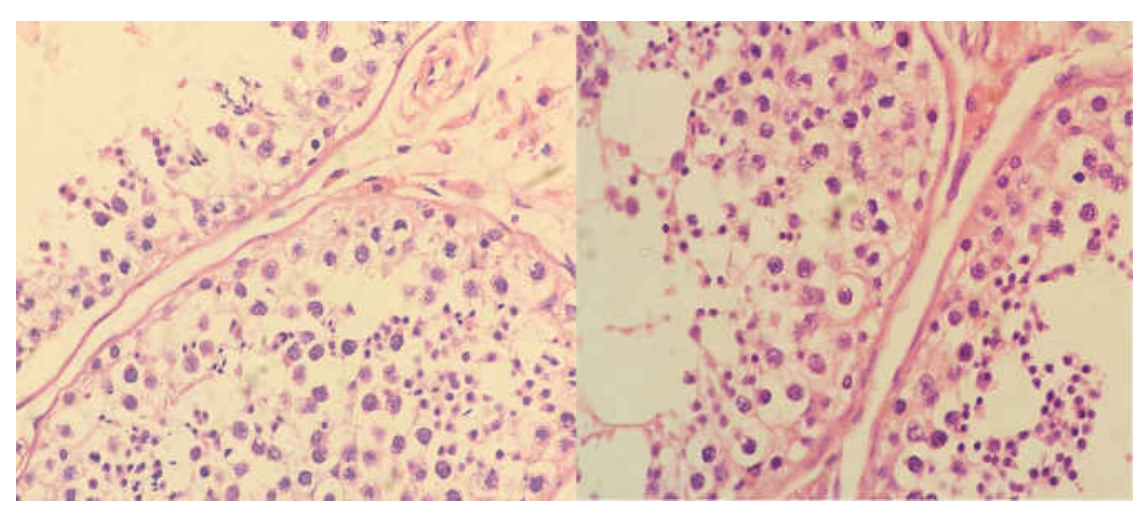

Figure 3: Sections from Testis processed by conventional (left) and microwave (right) ( HE stain, 10x).

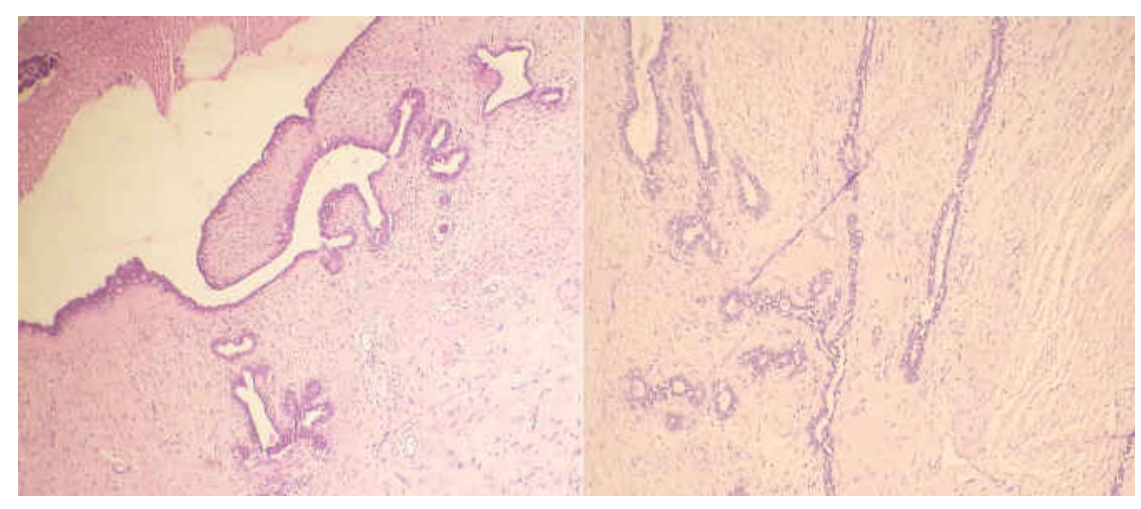

Figure 4: Sections from Breast processed by conventional (left) and microwave method (right) ( HE stain, 4x). 


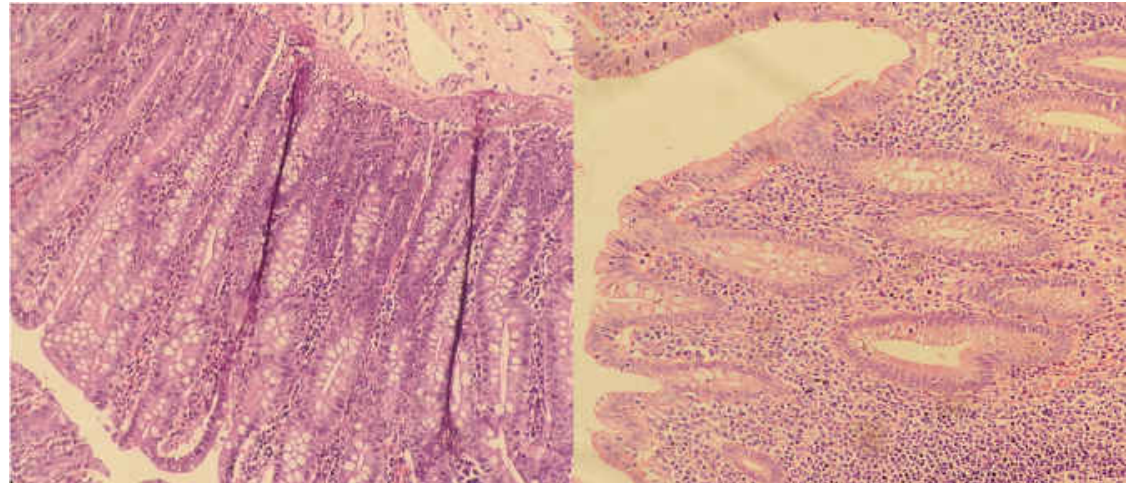

Figure 5: Sections from Intestine processed by conventional (left) and microwave method (right)(HE stain, 10x).

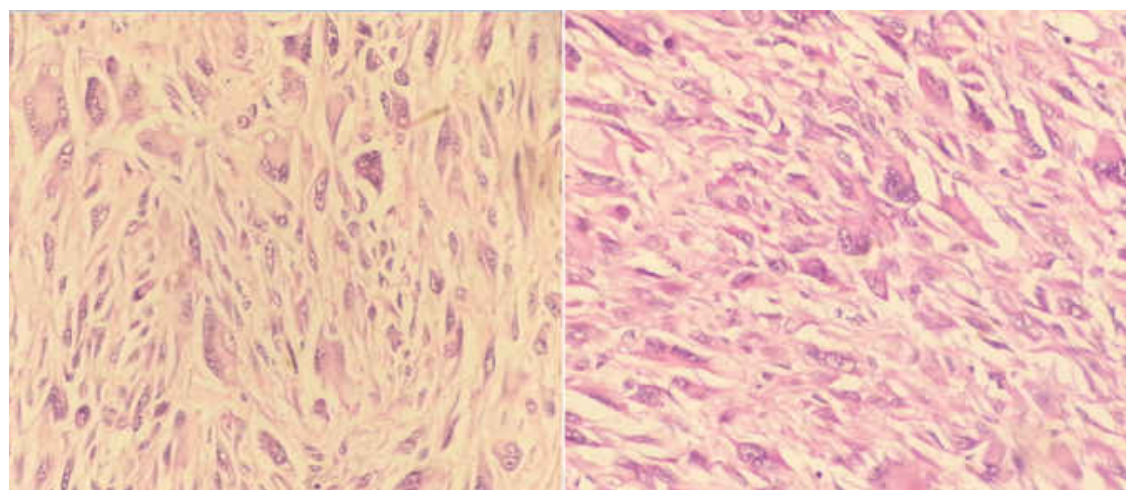

Figure 6: Sections from Soft tissue tumor processed by conventional (left) and microwave method (right) (HE stain, 40x).

\section{Scoring:}

Total of 200 slides (100 pairs) were evaluated by each observer: $\mathrm{O}^{1}$ and $\mathrm{O}^{2}$. Seven different parameters (1.Cellular clarity, 2.Cytoplasmic details, 3.Nuclear details, 4.Colour intensity, ${ }^{5}$.Interface of epithelium and connective tissue, 6.Fibrous tissue component and 7.Staining quality) were evaluated by two observers and independent scores were given as per obtained quality.

Scoring was done as follow:

Grade:1-Poor ; Grade:2- Average; Grade:3- Good; Grade:4- Excellent.

The resulting "combined scores" were employed for statistical analysis. Minimum possible combined score - 2 ; Maximum possible combined score -8 .

\section{Statistical methods employed}

Data were entered in MS-EXCEL 2007 and converted into SPSS 11.5 for statistical analysis. Wilcoxin signed ranks test was applied. P value $<0.05$ was considered statistically significant.

\section{RESULTS}

Score range observed for both conventional and microwave methods were graded Average to Excellent. The two methods did not show significant variation in terms of overall quality, consistent with the observations of numerous authors such as Rohr, Morales, Mathai, Devi, Babu. ${ }^{1-6}$ Complete concordance of opinion with regard to quality of the two methods was seen in an average of $90.42 \%$ cases. Majority of tissue sections were of excellent quality (Score-4). None of the slides were deemed 'poor'. There was no decrement in diagnostic utility of slides prepared by microwave method.

Cellular clarity, Colour intensity and overall Staining quality in our study was slightly higher for microwave method, in concordance with Babu et al.4 and Nangia et al. ${ }^{7}$ No statistically significant variation was observed between the two methods ( $\mathrm{p}>0.05$ ).

Cytoplasmic details, Nuclear details of most of the slides were interpreted uniformly good to excellent by two independent pathologists. Epithelium and connective tissue interface, Fibrous tissue component also remained similar in both the groups. Although there was no statistically 
significant variation observed between the two methods $(p>0.05)$, conventional method showed equal or slightly higher mean scores.

Mean scores for Cellular clarity (CC), Colour intensity (CI) and overall Staining quality (SQ) was slightly higher for microwave method but no statistically significant variation was observed between the two methods ( $>0.05$ ).

Complete concordance of opinion between the two methods with regard to quality was seen in an average of $90.42 \%$ cases. None of the slides were graded 'poor'.

End Temperature log was maintained after each step in every batch. The mean end temperature recorded by thermometer after dehydration step was $63.53^{\circ} \mathrm{C}$ (maximum $71^{\circ} \mathrm{C}$ and minimum $55^{\circ} \mathrm{C}$ ) and after clearing step was $75.53^{\circ} \mathrm{C}$ (maximum $78^{\circ} \mathrm{C}$ and minimum $73^{\circ} \mathrm{C}$ ).

\section{DISCUSSION}

Tissue processing requires removal of water molecules from the tissue to enable penetration of the embedding material into their space. This is accomplished slowly during Dehydration step using graded concentration of alcohol. ${ }^{8}$ During clearing step, reagents miscible with both dehydration and infiltration solutions are used that entirely replace the dehydrating solvents, giving way to impregnating reagents (Paraffin wax).

The physico chemical basis of tissue processing is the diffusion of reagents to the substance of the tissue to be processed which can be accelerated by applying heat. Heat increases the rate of penetration and fluid exchange and must be used sparingly to reduce the possibility of shrinkage, hardening or embrittlement of the tissue sample. ${ }^{8}$ Other factors influencing the rate of diffusion of reagents include exposed surface area of the tissue that is in contact with the processing reagents, agitation, viscosity and vacuum.

Microwaves have the advantage of uniform heating through-out the tissue matter as opposed to heat transfer mechanism from outside to inside in case of conventional method. This stimulates the diffusion of solutions into the tissue, thus accelerating the chemical reaction. However, microwave penetration can be altered / reduced by thick tissue sections and high fat content because of their lower water content. Different substances subjected to the same amount of microwave energy heat up at different rates. For instance, $100 \mathrm{ml}$ of water needs 2.2 times more heat to warm up than $100 \mathrm{ml}$ of alcohol. Whether or not heat is generated is determined by the specific dielectric properties of the material itself. In most materials, the microwavepower absorption is proportional to the water content of the material. ${ }^{8,9}$

Immersion of a tissue in liquid changes the temperature pattern within the tissue due to energy absorption in the liquid and the mechanism of heat flow at the borders. The volume of reagent plays an important role in determining heating rate and temperature uniformity within the tissue sample. The higher the volume of reagent, the less the mean heating rate and the better the heating uniformity inside the tissue sample. The use of water load improves temperature uniformity and prevents tissue overheating. Heating uniformity can be raised by $27 \%$ to $42.26 \%$ by raising the reagent volume from $100 \mathrm{ml}$ to $150 \mathrm{ml} .{ }^{10}$ We used $200 \mathrm{ml}$ of reagents in each step to minimize overshooting and to enhance heating uniformity inside the tissue sample.

In the present study, paraffin blocks were produced in 70 minutes using a microwave (60 minutes for processing and approximated 10 minutes for embedding), as compared to 7:30 minutes (12 hours 10 minutes) in a conventional tissue processor. This was followed by sectioning of paraffin blocks and Hematoxylin and Eosin staining of the slides. Adequate Hematoxylin staining could be achieved in 50 seconds with application of microwave while adequate Eosin staining could be achieved in 25 to 30 seconds. Macroscopically, processed tissues appeared well impregnated with paraffin wax and blocks were comfortably cut.

Noticeable difference was observed in tissues with high fat content. Fatty tissues naturally have less water content and usually require extended processing period as lipids, such as general body fats and myelin in brain tissues inhibit the diffusion of processing reagents. Smitha Naik K et al. observed in their study that integrity of adipose tissue was better in tissues processed by microwave. ${ }^{11}$ In our study, out of five fatty tissue sections included in the study, two microwave processed tissues and one conventionally processed tissue showed noticeably poor adipose tissue preservation.

Cytoplasmic details were well visualized in all the slides and also intercellular bridges, brush borders, cilia as observed by Kango et al. ${ }^{5}$ When evaluated individually, nuclear details were crisp, chromatin pattern, hyperchromasia, membrane irregularity of malignant lesions were well visualized in both methods and there was no disparity in terms of diagnosability.

Erythrocytes were intact in all microwave processed tissues as also observed by Kango et al. ${ }^{5}$ and Smitha Naik K et al. ${ }^{11}$ although Hopwood et al. ${ }^{12}$ claimed that red blood cells were prone to lysis after microwave treatment of tissues.

In current study, microwave group showed greater degree of eosinophilia. Hopwood et $\mathrm{al}^{12}$ and Leon et $\mathrm{al}^{13}$ noted eosinophilia in tissues fixed by microwaves, independent of the solution in which the tissues were processed. He also mentions that this eosinophilia was readily corrected by altering the staining time in eosin. Eosinophilia of the cytoplasm also produced greater enhancement of the 
nuclear-cytoplasmic contrast, according to Leong. Similar eosinophilia was noted by Kango et al. ${ }^{5}$

Two conventionally processed and stained tissue sections showed poor overall staining intensity. Epithelium and connective tissue interface was well preserved in tissue sections obtained from both the methods and scores obtained were similar. Marked difference was observed in one microwave processed tissue section from kidney which showed greater degree of stromal retraction than its conventional counterpart. Occasional tissue sections obtained by microwave method showed hyalinized appearance of fibrocollagenous tissue as compared to its conventional counterpart and this was unrelated to the underlying pathology.

\section{CONSLUSION}

This study has achieved reduced processing time, elimination of noxious chemicals and comparable microscopic features. No statistically significant variation was observed in overall quality of microwave processed and stained tissue sections and conventionally processed and stained tissue sections. Tissue morphology / architecture of lesions ranging from benign to malignant were well maintained and contribution to diagnostic utility was uncompromised.

Small tissue biopsies require less fixation time and can take advantage of microwave tissue processing method allowing same day reporting.

Increased efficiency through improved turnaround times, environmentally friendly reagents are well proven advantages of microwave system. Proper use of microwave system requires careful calibration and monitoring.

\section{Recommendation:}

Field of pathology is constantly evolving. Rapidity that microwave provides has made "same day reporting" a possibility. In present era this undoubtedly is a welcome change. Its positive contribution to early patient management, higher patient and doctor's satisfaction is undeniable.

This study has shown that the overall quality of tissues processed and stained by a manually operated microwave was at par with the conventional method. In our experience comparable result was attained owing to selection of the best working protocol prior to conducting the study. Therefore it is recommended that protocols be modified to suit local practices and working environment.

Microwave tissue processing can be implemented in Diagnostic pathology laboratories handling small number of specimeneveryday.
In view of the high sample load at a tertiary care center, labor cost that manually operated microwave demands may be restrictive. However, certain cases that require initiation of appropriate therapy demand rapid diagnosis and may benefit from this method.

\section{REFERENCES}

1. Rohr LR, Layfield LJ, Wallin D, Hardy D. A comparison of routine and rapid microwave tissue processing in a surgical pathology laboratory. Quality of histologic sections and advantages of microwave processing. Am J Clin Pathol. 2001 May;115:703-8. Crossref

2. Morales AAR, Nassiri M, Kanhoush R, Vincek V, Nadji M. Experience with an automated microwave-assisted rapid tissue processing method: validation of histologic quality and impact on the timeliness of diagnostic surgical pathology. Am J Clin Pathol. 2004;121:528-36. Crossref

3. Mathai AM, Naik R, Pai MR, Rai S, Baliga P. Microwave histoprocessing versus conventional histoprocessing. Indian J Pathol Microbiol. 2008;51:12-6. Crossref

4. Babu TM, Malathi N, Magesh KT. A comparative study on microwave and routine tissue processing. Indian J Dent Res. 22:50-5. Crossref

5. Kango PG, Deshmukh R. Microwave processing: A boon for oral pathologists. J Oral Maxillofac Pathol 2011;15:6-13. Crossref

6. Devi R B, A R S, Parameaswari PJ, Parijatham BO. Domestic microwave versus conventional tissue processing: a quantitative and qualitative analysis. J Clin Diagn Res. 2013;7:835-9. Crossref

7. Nangia R, Negi A, Puri A, Bansal S, Gupta R, Mittal M. Comparison of conventional tissue processing with microwave processing using commercially available and domestic microwaves. Indian J Oral Sci. 2013;4:64. Crossref

8. Bancroft JD, Gamble M. Bancroft's Theory and Practice of Histological Techniques. 7th ed. Kim S Suvarna, S. Kim Suvarna, Christopher Layton JDB, editor. Elsevier Health Sciences; 2008. $725 \mathrm{p}$.

9. McArdle P. Microwave processing techniques for microscopy [Internet]. Available from: Crossref

10. Hassan OA, Kandil AH, El Bialy AM, Hassaballa IA. Improving heating uniformity of pathological tissue specimens inside a domestic microwave oven. J Microw Power Electromagn Energy. 2013;47:87101. Crossref

11. K SN, Patel S, Astekar M, Rao D. Comparison of clarity of nucleocytoplasmic differentiation of oral tissues processed by microwave and conventional methods. Ann Diagn Pathol. Elsevier Inc.; 2012;16:128-33.

12. Hopwood D, Coghill G, Ramsay J, Milne G, Kerr M. Microwave fixation: its potential for routine techniques, histochemistry, immunocytochemistry and electron microscopy. Histochem J. 1984;16:1171-91. Crossref

13. Leong AS. Microwave irradiation in histopathology. Pathol Annu 1998;23:213-33. Crossref 